\title{
EFEKTIVITAS MODEL PEMBELAJARAN TERHADAP PENINGKATAN PEMAHAMAN KONSEP FISIKA SISWA SMA: META-ANALISIS
}

\author{
M. Ifdal Hafiz Chan'), Edja Annisa Septia ${ }^{1)}$, Kurnia Febrianti ${ }^{1)}$, Desnita1) \\ 1)Program Studi Pendidikan Fisika, FMIPA, Universitas Negeri Padang, Sumatera Barat, Indonesia \\ Corresponding author : M. Ifdal Hafiz Chan \\ E-mail : m.id.hfz.chan@gmail.com
}

Diterima 22 Juni 2021, Direvisi 08 Juli 2021, Disetujui 12 Juli 2021

\begin{abstract}
ABSTRAK
Tujuan dari penelitian ini adalah untuk melihat efektivitas dari beberapa model pembelajaran dalam meningkatkan pemahaman konsep fisika siswa SMA. Penelitian ini merupakan penelitian meta-analisis yang menggambarkan effect size dari penelitian-penelitian pendidikan mengenai pengaruh modelmodel pembelajaran terhadap pemahaman konsep fisika siswa SMA. Model pembelajaran yang di bandingkan dalam penelitian meta-analisis ini adalah model pembelajaran Discovery Learning, Inkuiri, Kooperatif, Direct Instruction, dan Problem Based Learning. Model pembelajaran yang memiliki efektivitas tertinggi adalah model pembelajaran Langsung (Direct Instruction) dengan nilai rata-rata effect size 1.43 yang termasuk dalam kategori tinggi. Model pembelajaran lain yang juga memiliki nilai rata-rata effect size yang termasuk dalam kategori tinggi adalah model pembelajaran Inkuiri dengan nilai rata-rata effect size 1.39, model pembelajaran Kooperatif dengan nilai rata-rata effect size 1.11, model pembelajaran Discovery Learning dengan nilai rata-rata effect size 0.96, serta model pembelajaran Problem Based Learning dengan nilai rata-rata effect size 0.92.
\end{abstract}

Kata kunci: Meta-Analisis; Discovery Learning; Inkuiri; Kooperatif; Direct Instruction; Problem Based Learning; Pemahaman Konsep; Fisika

\begin{abstract}
The purpose of this study was to see the effectiveness of several learning models in improving the understanding of physics concepts for high school students. This research is a meta-analysis that describes the effect size of educational studies regarding the influence of learning models on the understanding of physics concepts for high school students. The learning models compared in this metaanalysis are the Discovery Learning, Inquiry, Cooperative, Direct Instruction, and Problem Based Learning learning models. The learning model that has the highest effectiveness is the Direct Instruction model with an average effect size value of 1.43 which is included in the high category. Other learning models that also have an average effect size value that is included in the high category are the Inquiry learning model with an average effect size value of 1.39, the Cooperative learning model with an average effect size value of 1.11 , and the Discovery Learning learning model with an average value. the average effect size is 0.96, as well as the Problem Based Learning model with an average effect size value of 0.92 .
\end{abstract}

Keywords: Meta-Analysis; Discovery Learning; Inquiry; Cooperative; Direct Instruction; Problem Based Learning; Concept Understanding; Physics.

\section{PENDAHULUAN}

Kurikulum 2013 yang diterapkan di Indonesia saat ini merupakan usaha mengimplementasikan tuntutan pembelajaran yang sesuai abad 21. Kurikulum 2013 mensyaratkan pembelajaran harus responsif terhadap perkembangan ilmu pengetahuan, teknologi, seni, dan budaya untuk membangun rasa ingin tahu dan kemampuan siswa (Kemendikbud, 2014). Belajar di abad 21 harusnya berpusat pada siswa dan kolaboratif (Asrizal, Amran, Ananda, Festiyed, \& Sumarmin, 2018). Peserta didik memiliki peran yang lebih banyak dalam menemukan konsep atau pengetahuan baru (Pratiwi, 2019). Siswa dituntut untuk dapat memahami apa yang dipelajarinya. Dengan demikian, seorang guru harus memiliki kemampuan untuk dapat mengembangkan pengajaran materi yang divariasikan, sehingga pembelajaran tidak monoton dan tidak membosankan bagi siswa (Amila, Abdurrahman, Suyatna, Wayan, \& Herlina, 2018).

Fisika merupakan bagian dari ilmu sains yang mempelajari hukum-hukum alam. Fisika merupakan pengetahuan, gagasan dan 
konsep tentang alam sekitar yang diper oleh dari pengalaman melalui pengamatan dan diaplikasikan dalam dunia nyata (Prihatiningtyas, S., Prastowo, T.,\&Jatmiko, B.; 2013). Tujuan pembelajaran Fisika di Sekolah Menengah Atas (SMA) diantaranya adalah agar peserta didik mempunyai kemampuan penguasaan konsep dan prinsip fisika, memiliki keterampilan mengembangkan pengetahuan dan sikap percaya diri sebagai bekal melanjutkan pendidikan pada jenjang yang lebih tinggi serta mengembangkan ilmu pengetahuan dan teknologi (Departemen Pendidikan Nasional, 2006).

Dalam pembelajaran fisika, salah satu bagian penting yang harus dimiliki siswa ialah menguasai konsep, karena konsep tersebut digunakan untuk membangun pengetahuan baru dan untuk menyelesaikan permasalahan (Arend,2012). Pada hakikatnya, pemahaman konsep ialah proses perbuatan untuk benarbenar mengerti mengenai suatu rancangan atau suatu ide abstrak yang memungkinkan seseorang untuk menggolongkan suatu objek maupun kejadian (Elisa, 2017). Anderson dan Krathwohl (2001), mengatakan bahwa, dengan penguasaan konsep, peserta didik dapat meningkatkan kemahiran intelektualnya untuk membantu dalam proses memecahkan persoalan serta dapat menimbulkan pembelajaran yang bermakna. Pada kenyataannya, dari beberapa artikel yang digunakan sebagai acuan dalam pembuatan metaanalisis ini, pemahaman konsep fisika yang dimiliki siswa masih rendah. Menurut Sari et al. (2016) bahwa rendahnya pemahaman konsep fisika disebabkan karena kesulitan peserta didik dalam memahami konsep fisika yang tergolong abstrak.

Menurut Hikmawati et al. (2020) faktor yang mempengaruhi rendahnya penguasaan konsep fisika ialah karena penggunaan model pembelajaran yang tidak sesuai dengan materi yang diajarkan. Menurut Shoimin (2014) di zaman yang modern ini, sebagian besar guru mengajar menggunakan metode pengajaran yang konvensional, dengan cara mengajar berpusat pada guru (teacher centered) serta masih menggunakan metode ceramah.

Beberapa permasalahan yang dihadapi lainnya pada saat proses pembelajaran fisika diantaranya adalah sebagai berikut: 1) peserta didik kurang berminat mengikuti pembelajaran fisika, 2) pada proses pembelajaran fisika sangat jarang dilakukannya praktikum, 3) laboratorium fisika tidak digunakan sebagai tempat praktikum , tetapi dialihfungsikan pada kegiatan lainnya. Permasalahan tersebut menyebabkan peserta didik memiliki anggapan bahwa pembelajaran yang dilakukan tidak bermakna dan tidak bermanfaat, sebab tidak ada kaitan antara pembelajaran yang dilakukan dengan peristiwa yang terjadi dalam kehidupan nyata di sekitarnya. Anggapan seperti inilah yang menjadi faktor pemicu hasil belajar fisika peserta didik masih rendah. Karena rendahnya hasil belajar peserta didik tersebut, maka menjadi salah satu indikator rendahnya penguasaan konsep siswa (Turrahmah, 2019). Berdasarkan observasi oleh Ute at al (2021) proses pembelajaran di kelas lebih menekankan pada penjelasan materi secara ceramah dan latihan soal-soal, Sehingga banyak siswa yang merasa jenuh dan kurang menyukai pelajaran fisika

Untuk mengatasi permasalahan diatas, perlu dilakukan perubahan dalam segi model pembelajaran yang dapat berpengaruh baik terhadap motivasi belajar dan pemahaman konsep fisika siswa. Model pembelajaran merupakan prosedur sistematis yang digunakan untuk mencapai tujuan pembelajaran yang memuat strategi, teknik, metode, bahan, media, dan instrumen pembelajaran (Afandi, 2013). Guru dapat memilih model pembelajaran yang sesuai untuk mencapai tujuan pembelajaran yang ditetapkan dengan mempertimbangkan : 1) tujuan yang hendak dicapai; 2) materi pembelajaran; 3) peserta didik; dan 4) pertimbangan nonteknis (Nurdyansyah, 2016)

Beberapa studi telah dilakukan mengenai peningkatan pemahaman konsep fisika siswa SMA. Secara umum artikel metaanalisis ini mengacu pada 20 artikel mengenai model pembelajaran terhadap peningkatan pemahaman konsep siswa. Beberapa kelompok model pembelajaran tersebut ialah model pembelajaran discovery, model pembelajaran inkuiri, model pembelajaran kooperatif, model pembelajaran direct instruction dan model pembelajaran problem based learning. Kelima kelompok model ini merupakan kelompok model yang paling banyak digunakan dalam proses pembelajaran dan dinilai memberikan pengaruh pada prose pembelajaran,salah satunya ialah dalam peningkatan pemahaman konsep siswa. Berdasarkan hasil penelitian salah satu artikel dari kelompok model pembelajaran discovery menyatakan bahwa penerapan discovery learning berbantuan media laboratorium virtual berpengaruh terhadap penguasaan konsep fisika siswa. Hal ini ditunjukkan dengan peningkatan nilai rata-rata penguasaan konsep pada siswa yang diajarkan dengan discovery learning berbantuan media laboratorium virtual lebih tinggi dibandingkan dengan siswa yang diajarkan menggunakan pembelajaran konvensional (Putri Iman Sari et al, 2016). Hasil 
penelitian salah satu artikel dari kelompok model pembelajaran inkuiri menyatakan bahwa berdasarkan hasil dan analisis data penelitian terdapat pengaruh model pembelajaran inkuiri dengan alat sains sederhana terhadap pemahaman konsep fluida statis siswa (Husnia, 2019). Hasil penelitian salah satu artikel dari kelompok model pembelajaran kooperatif, menyatakan bahwa terdapat pengaruh model pembelajaran kooperatif tipe SFAE berbantuan komik edukatif terhadap pemahaman konsep fisika siswa kelas X SMA Negeri 1 Palu (Nursyamsi, 2020). Hasil penelitian salah satu artikel dari kelompok model pembelajaran direct instruction menyatakan bahwa terdapat pengaruh model pembelajaran direct instruction kobinasi multimedia terhadap motivasi dan pemahaman konsep fisika pada siswa kelas XI IPA MA DI Putri Nurul Hakim Tahun pelajaran 2017/2018 (Safitri,2018). Dan hasil penelitian salah satu artikel dari kelompok model pembelajaran problem based learning, menyatakan bahwa siswa yang belajar dengan menggunakan model problem based learning menunjukkan pemahaman konsep belajar fisika siswa lebih tinggi dibandingkan kelompok siswa yang dengan model pembelajaran langsung, sehingga penerapan model problem based learning memberikan konstribusi yang positif bagi siswa sehingga dapat diterapkan nantinya pada proses pembelajaran fisika (Aristawati, 2018).

Meskipun sudah sekian banyak penelitian mengenai model pembelajaran terhadap peningkatan pemahaman konsep siswa, akan tetapi masih belum memberikan kesimpulan yang universal. Atas dasar hal tersebut, maka perlu adanya metaanalisis efektivitas model pembelajaran dalam meningkatkan pemahaman konsep fisika siswa. Rumusan masalah penelitian ini adalah model pembelajaran manakah yang yang lebih efektif untuk digunakan dalam meningkatkan pemahaman konsep fisika siswa ditinjau dari hasil belajar yang di dapat setelah model pembelajaran diterapkan. Tujuan dari penelitian ini adalah untuk melihat efektivitas dari beberapa model pembelajaran dalam meningkatkan pemahaman konsep fisika siswa SMA.

\section{METODE PENELITIAN}

Penelitian ini merupakan penelitian meta-analisis yang menggambarkan effect size dari penelitian-penelitian pendidikan mengenai pengaruh model-model pembelajaran terhadap pemahaman konsep fisika siswa SMA.

Pertama, peneliti menetapkan rumusan masalah. Rumusan masalah yang ditetapkan pada penelitian ini adalah pengaruh model pembelajaran terhadap pemahaman konsep fisika siswa, model pembelajaran disini dibatasi ke dalam lima jenis model pembelajaran, diantaranya Discovery Learning, Inkuiri, Kooperatif, Direct Instruction, dan Problem Based Learning. Kedua, peneliti mengumpulkan dan memilih artikel jurnal yang relevan dengan rumusan masalah yang akan diteliti, artikel yang dikumpulkan berjumlah 20 artikel yang diterbitkan pada berbagai jurnal, diantaranya: Jurnal Pendidikan Fisika dan Teknologi; Jurnal IImiah Profesi Pendidikan; Jurnal Sains dan Pendidikan Fisika (JSPF); Jurnal Pijar MIPA; JPF (Jurnal Pendidikan Fisika) FKIP UM Metro; Radiasi; Jurnal Ikatan Alumni Fisika Universitas Negeri Medan; Jurnal Pendidikan Fisika Tadulako Online (JPFT); JPF (Jurnal Pendidikan Fisika Universitas Muhammadiyah Metro); Media Eksakta; UPEJ (Unnes Physics Education Journal); Jurnal IImiah IKIP Mataram; Jurnal IImiah Pendidikan Fisika "Lensa"; Jurnal Inovasi Pendidikan Fisika (JIPF); JPPF; Indonesian Journal of Science and Mathematics Education; dan Formatif: Jurnal IImiah Pendidikan MIPA. Ketiga, peneliti menghitung besar effect size dari hasil yang di dapat oleh penelitian pada artikel yang telah dikumpulkan. Perhitungan dilakukan menggunakan rumus yang sesuai dengan data yang tersedia pada artikel tersebut. Keempat, peneliti mengambil rata-rata dari effect size tersebut dan mengkategorikannya kedalam kategori berikut: efektivitas model pembelajaran Discovery Learning dengan pendekatan yang berbeda, efektivitas model pembelajaran Inkuiri dengan pendekatan yang berbeda, efektivitas model pembelajaran Koperatif dengan pendekatan yang berbeda, efektivitas model pembelajaran Direct Instruction dengan pendekatan yang berbeda, efektivitas model pembelajaran Problem Based Learning dengan pendekatan yang berbeda, serta perbandingan efektivitas dari kelima model pembelajaran tersebut. Kelima, peneliti membuat kesimpulan dari penelitian ini secara deskriptif.

Effect size dapat didefinisikan sebagai besarnya efek antara dua atau lebih variabel yang dinyatakan dalam ES (Izzah, 2021). Berikut adalah beberapa rumus yang digunakan dalam menentukan effect size Cohen's d dari hasil uji-t dan uji-F dalam statistik dikutip dari Thalheimer (2002):

1) Untuk hasil uji-t yang memiliki nilai rata-rata kelas kontrol dan kelas yang diberikan perilaku serta standar deviasi, maka dapat digunakan rumus berikut :

$$
d=\frac{\overline{x_{t}}-\overline{x_{c}}}{S_{\text {pooled }}}
$$




$$
S_{\text {pooled }}=\sqrt{\frac{\left(n_{t}-1\right) s_{t}^{2}+\left(n_{c}-1\right) s_{c}^{2}}{n_{t}+n_{c}}}
$$

2) Untuk hasil uji-t tanpa standar deviasi atau standar error, maka dapat digunakan :

$$
\begin{gathered}
d=t \sqrt{\left(\frac{n_{t}+n_{c}}{n_{t} n_{c}}\right)\left(\frac{n_{t}+n_{c}}{n_{t}+n_{c}-2}\right)} \\
d \approx \frac{2 t}{\sqrt{n-2}}
\end{gathered}
$$

3) Untuk hasil uji-F dengan mean squared error, maka dapat digunakan :

$$
d=\frac{\overline{x_{t}}-\overline{x_{c}}}{M S E \sqrt{\left(\frac{n_{t}+n_{c}-2}{n_{t}+n_{c}}\right)}}
$$

4) Untuk hasil uji-F tanpa mean squared error, maka dapat digunakan :

$$
d=\sqrt{F\left(\frac{n_{t}+n_{c}}{n_{t} n_{c}}\right)\left(\frac{n_{t}+n_{c}}{n_{t}+n_{c}-2}\right)}
$$

Pada penulisan artikel ini, peneliti mengumpulkan dua puluh artikel dari berbagai jurnal yang memiliki kesamaan pada variabel yang dibahas dalam artikel ini. Berikut adalah

\begin{tabular}{|c|c|c|}
\hline $\begin{array}{c}\text { No. } \\
\text { Artikel }\end{array}$ & Identitas Artikel & $\begin{array}{l}\text { Jumlah } \\
\text { Sampel }\end{array}$ \\
\hline 1 & Sari, dkk. (2016) & 72 \\
\hline 2 & $\begin{array}{l}\text { Rosmiati, dkk. } \\
(2020)\end{array}$ & 59 \\
\hline 3 & $\begin{array}{l}\text { Destalina, dkk. } \\
\text { (2019) }\end{array}$ & 67 \\
\hline 4 & $\begin{array}{l}\text { Turrahmah, dkk. } \\
(2019)\end{array}$ & 51 \\
\hline 5 & Ute, dkk. (2021) & 74 \\
\hline 6 & Adam, dkk. (2016) & 57 \\
\hline 7 & Wati, dkk. (2019) & 56 \\
\hline 8 & $\begin{array}{l}\text { Husnia, dkk. } \\
(2019)\end{array}$ & 40 \\
\hline 9 & $\begin{array}{l}\text { Agustina, dkk. } \\
(2020)\end{array}$ & 72 \\
\hline 10 & $\begin{array}{l}\text { Nursyamsi, dkk. } \\
(2020)\end{array}$ & 62 \\
\hline 11 & Riyadi, dkk. (2014) & 73 \\
\hline 12 & $\begin{array}{l}\text { Mawarsih, dkk. } \\
(2016)\end{array}$ & 60 \\
\hline
\end{tabular}
identitas dari artikel yang sudah penulis kumpulkan dan akan di lakukan analisis terhadap effect size nya :

Tabel 1 Identitas Artikel

\begin{tabular}{rlc}
\hline 13 & Safitri, dkk. (2018) & 41 \\
\hline 14 & $\begin{array}{l}\text { Purnamasari, dkk. } \\
(2016)\end{array}$ & 57 \\
\hline 15 & Arianti, dkk. (2016) & 48 \\
\hline 16 & $\begin{array}{l}\text { Supriyanto, dkk. } \\
\text { (2017) }\end{array}$ & 75 \\
\hline 17 & $\begin{array}{l}\text { Aristawati, dkk. } \\
(2018)\end{array}$ & 69 \\
\hline 18 & $\begin{array}{l}\text { Yulianti, dkk. } \\
\text { (2019) }\end{array}$ & 70 \\
\hline 19 & Diani, dkk. (2019) & $\begin{array}{c}\text { Tidak } \\
\text { Dilaporkan }\end{array}$ \\
\hline 20 & Taqwa, dkk. (2019) & 34 \\
\hline
\end{tabular}

Effect size yang didapat dari artikelartikel di atas nantinya akan di kelompokkan berdasarkan jenis model pembelajaran yang dibahas oleh artikel tersebut, diantaranya: kelompok model pembelajaran Discovery Learning, kelompok model pembelajaran Inkuiri, kelompok model pembelajaran Kooperatif, kelompok model pembelajaran Direct Instruction, dan kelompok model pembelajaran Problem Based Learning. Setelah rata-rata effect size dari masing masing kelompok di dapatkan, maka rata-rata tersebut dibandingkan untuk melihat model pembelajaran mana diantara lima model pembelajaran yang dibahas, yang memiliki efektivitas tertinggi dalam meningkatkan pemahaman konsep fisika siswa SMA.

Hasil analisis effect size berikutnya akan di kategorikan berdasarkan kriteria berikut

Tabel 2 Pengkategorian Effect Size

\begin{tabular}{cc}
\hline $\begin{array}{c}\text { Nilai Effect } \\
\text { Size }\end{array}$ & Kategori \\
\hline $0 \leq \mathrm{ES} \leq 0.2$ & Rendah \\
\hline $0.2<\mathrm{ES}<0.8$ & Sedang \\
\hline $0.8 \leq \mathrm{ES}$ & Tinggi
\end{tabular}

(Cohen, 1988) 
HASIL DAN PEMBAHASAN

Perbandingan Effect Size Dalam Kelompok Model Pembelajaran

\section{Model Pembelajaran Discovery Learning}

Tabel 3 Model Pembelajaran Discovery Learning

\begin{tabular}{clc}
\hline $\begin{array}{c}\text { No. } \\
\text { Artikel }\end{array}$ & $\begin{array}{c}\text { Model } \\
\text { Pembelajaran }\end{array}$ & $\begin{array}{c}\text { Effect } \\
\text { Size }\end{array}$ \\
\hline 1 & $\begin{array}{l}\text { Discovery Learning } \\
\text { Berbantuan } \\
\text { Laboratorium } \\
\text { Virtual }\end{array}$ & 1.14 \\
\hline 2 & $\begin{array}{l}\text { Discovery Learning } \\
3\end{array}$ & 1.31 \\
\hline 4 & $\begin{array}{l}\text { Discovery Learning } \\
\text { Berorientasi Inquiry }\end{array}$ & 0.79 \\
& $\begin{array}{l}\text { Discovery Learning } \\
\text { Berbantuan Alat } \\
\text { Praktikum }\end{array}$ & 0.61 \\
\hline Rata-rata Effect Size (R1) & 0.96 \\
\hline
\end{tabular}

Berdasarkan hasil perhitungan effect size untuk kelompok artikel yang membahas mengenai pengaruh model pembelajaran Discovery Learning terhadap pemahaman konsep fisika siswa SMA, didapatkan bahwa model pembelajaran yang memiliki efektivitas tertinggi adalah model pembelajaran Discovery Learning dengan nilai effect size 1.31 yang termasuk dalam kategori tinggi. Model pembelajaran Discovery Learning Berbantuan Laboratorium Virtual juga termasuk dalam kategori tinggi dengan nilai effect size 1.14.

Setelah dilakukan perhitungan untuk menentukan rata-rata effect size dari model pembelajaran Discovery Learning, didapatkan hasil nilai effect size 0.96 yang termasuk dalam kategori tinggi.

\section{Model Pembelajaran Inkuiri}

Tabel 4 Model Pembelajaran Inkuiri

\begin{tabular}{ccc}
\hline $\begin{array}{c}\text { No. } \\
\text { Artikel }\end{array}$ & $\begin{array}{c}\text { Model } \\
\text { Pembelajaran }\end{array}$ & $\begin{array}{c}\text { Effect } \\
\text { Size }\end{array}$ \\
\hline 5 & Inkuiri Terbimbing & 1.6 \\
\hline 6 & Guided Inquiry & 1.12 \\
\hline 7 & $\begin{array}{l}\text { Inkuiri Berbantuan } \\
\text { Pocket Book }\end{array}$ & 0.93 \\
\hline
\end{tabular}

\begin{tabular}{ccc}
\hline 8 & $\begin{array}{l}\text { Inkuiri dengan Alat } \\
\text { Sains Sederhana }\end{array}$ & 1.91 \\
\hline Rata-rata Effect Size (R2) & 1.39 \\
\hline
\end{tabular}

Berdasarkan hasil perhitungan effect size untuk kelompok artikel yang membahas mengenai pengaruh model pembelajaran Inkuiri terhadap pemahaman konsep fisika siswa SMA, didapatkan bahwa model pembelajaran yang memiliki efektivitas tertinggi adalah model pembelajaran Inkuiri dengan Alat Sains Sederhana dengan nilai effect size 1.91 yang termasuk dalam kategori tinggi. Model pembelajaran Inkuiri Terbimbing, Guided Inquiry, dan Inkuiri Berbantuan Pocket Book juga termasuk dalam kategori tinggi dengan nilai effect size masing-masing 1.6, 1.12, dan 0.93 .

Setelah dilakukan perhitungan untuk menentukan rata-rata effect size dari model pembelajaran Inkuiri, didapatkan hasil nilai effect size 1.39 yang termasuk dalam kategori tinggi.

\section{Model Pembelajaran Kooperatif}

Tabel 5 Model Pembelajaran Kooperatif

\begin{tabular}{clc}
\hline $\begin{array}{c}\text { No. } \\
\text { Artikel }\end{array}$ & $\begin{array}{c}\text { Model } \\
\text { Pembelajaran }\end{array}$ & $\begin{array}{c}\text { Effect } \\
\text { Size }\end{array}$ \\
\hline \multicolumn{3}{c}{$\begin{array}{l}\text { Kooperatif Tipe } \\
\text { Team Games } \\
\text { Tournament }\end{array}$} \\
\hline $\begin{array}{l}\text { Kooperatif Tipe } \\
\text { SFAE Berbantuan } \\
\text { Komik Edukatif }\end{array}$ & 1.7 \\
\hline 11 & $\begin{array}{l}\text { Kooperatif Tipe } \\
\text { NHT }\end{array}$ & 0.87 \\
\hline 12 & $\begin{array}{l}\text { Kooperatif Student } \\
\text { Facilitator and } \\
\text { Explaining }\end{array}$ & 0.82 \\
\hline Rata-rata Effect Size (R3) & 1.11 \\
\hline
\end{tabular}

Berdasarkan hasil perhitungan effect size untuk kelompok artikel yang membahas mengenai pengaruh model pembelajaran Kooperatif terhadap pemahaman konsep fisika siswa SMA, didapatkan bahwa model pembelajaran yang memiliki efektivitas tertinggi adalah model pembelajaran Kooperatif Tipe Team Games Tournament dengan nilai effect size 1.7 yang termasuk dalam kategori tinggi. Model pembelajaran Kooperatif Tipe SFAE Berbantuan Komik Edukatif, Kooperatif Tipe NHT, dan Kooperatif Student Facilitator and Explaining juga termasuk dalam kategori tinggi dengan nilai effect size masing-masing 1.04, 0.87 , dan 0.82 . 
Setelah dilakukan perhitungan untuk menentukan rata-rata effect size dari model pembelajaran Kooperatif, didapatkan hasil nilai effect size 1.11 yang termasuk dalam kategori tinggi.

\section{Model Pembelajaran Langsung (Direct Instruction)}

Tabel 6 Model Pembelajaran Langsung (Direct Instruction)

\begin{tabular}{clc}
\hline $\begin{array}{c}\text { No. } \\
\text { Artikel }\end{array}$ & \multicolumn{1}{c}{$\begin{array}{c}\text { Model } \\
\text { Pembelajaran }\end{array}$} & $\begin{array}{c}\text { Effect } \\
\text { Size }\end{array}$ \\
\hline 13 & $\begin{array}{l}\text { Direct Instruction } \\
\text { Kombinasi } \\
\text { Multimedia }\end{array}$ & 1.04 \\
& $\begin{array}{l}\text { Direct Instruction } \\
\text { dengan } \\
\text { Pendekatan } \\
\text { Kontekstual }\end{array}$ & 2.61 \\
\hline 14 & $\begin{array}{l}\text { Direct Instruction } \\
\text { Berbantuan } \\
\text { Simulasi Virtual }\end{array}$ & 0.75 \\
\hline Direct Instruction \\
dengan Strategi \\
Mind Mapping
\end{tabular}

Berdasarkan hasil perhitungan effect size untuk kelompok artikel yang membahas mengenai pengaruh model pembelajaran Langsung (Direct Instruction) terhadap pemahaman konsep fisika siswa SMA, didapatkan bahwa model pembelajaran yang memiliki efektivitas tertinggi adalah model pembelajaran Direct Instruction dengan Pendekatan Kontekstual dengan nilai effect size 2.61 yang termasuk dalam kategori tinggi. Model pembelajaran Direct Instruction dengan Strategi Mind Mapping, dan Direct Instruction Kombinasi Multimedia juga termasuk dalam kategori tinggi dengan nilai effect size masingmasing 1.33, dan 1.04.

Setelah dilakukan perhitungan untuk menentukan rata-rata effect size dari model pembelajaran Langsung (Direct Instruction), didapatkan hasil nilai effect size 1.43 yang termasuk dalam kategori tinggi.

\section{Model Pembelajaran Problem Based Learning}

Tabel 7 Model Pembelajaran Problem Based Learning

\begin{tabular}{clc}
$\begin{array}{c}\text { No. } \\
\text { Artikel }\end{array}$ & \multicolumn{1}{c}{$\begin{array}{c}\text { Model } \\
\text { Pembelajaran }\end{array}$} & $\begin{array}{c}\text { Effect } \\
\text { Size }\end{array}$ \\
\hline 17 & $\begin{array}{l}\text { Problem Based } \\
\text { Learning }\end{array}$ & 1.12 \\
\hline 18 & $\begin{array}{l}\text { Problem Based } \\
\text { Learning }\end{array}$ & 0.36 \\
\hline
\end{tabular}

\begin{tabular}{clc}
\hline 19 & $\begin{array}{l}\text { Problem Based } \\
\text { Instruction dengan } \\
\text { Scaffolding }\end{array}$ & 1.29 \\
\hline 20 & $\begin{array}{l}\text { Problem Based } \\
\text { Learning }\end{array}$ & 0.93 \\
\hline Rata-rata Effect Size (R5) & 0.92 \\
\hline
\end{tabular}

Berdasarkan hasil perhitungan effect size untuk kelompok artikel yang membahas mengenai pengaruh model pembelajaran Problem Based Learning terhadap pemahaman konsep fisika siswa SMA, didapatkan bahwa model pembelajaran yang memiliki efektivitas tertinggi adalah model pembelajaran Problem Based Instruction dengan Scaffolding dengan nilai effect size 1.29 yang termasuk dalam kategori tinggi. Model pembelajaran Problem Based Learning (Artikel Nomor 17), dan Problem Based Learning (Artikel Nomor 20) juga termasuk dalam kategori tinggi dengan nilai effect size masing-masing 1.12, dan 0.93.

Setelah dilakukan perhitungan untuk menentukan rata-rata effect size dari model pembelajaran Problem Based Learning, didapatkan hasil nilai effect size 0.92 yang termasuk dalam kategori tinggi.

\section{Perbandingan Effect Size Antar Kelompok Model Pembelajaran}

Tabel 8 Perbandingan Effect Size Antar Kelompok Model Pembelajaran

\begin{tabular}{clc}
\hline $\begin{array}{c}\text { No. } \\
\text { Kelompok }\end{array}$ & \multicolumn{1}{c}{$\begin{array}{c}\text { Model } \\
\text { Pembelajaran }\end{array}$} & $\begin{array}{c}\text { Rata- } \\
\text { rata ES }\end{array}$ \\
\hline R1 & $\begin{array}{l}\text { Discovery } \\
\text { Learning }\end{array}$ & 0.96 \\
\hline R2 & Inkuiri & 1.39 \\
\hline R3 & Kooperatif & 1.11 \\
\hline R4 & $\begin{array}{l}\text { Langsung (Direct } \\
\text { Instruction) }\end{array}$ & 1.43 \\
\hline R5 & $\begin{array}{l}\text { Problem Based } \\
\text { Learning }\end{array}$ & 0.92 \\
\hline
\end{tabular}

Berdasarkan hasil perhitungan ratarata effect size untuk lima kelompok artikel yang membahas mengenai pengaruh model pembelajaran yang berbeda terhadap pemahaman konsep fisika siswa SMA, didapatkan bahwa model pembelajaran yang memiliki efektivitas tertinggi adalah model pembelajaran Langsung (Direct Instruction) dengan nilai rata-rata effect size 1.43 yang termasuk dalam kategori tinggi.

Model pembelajaran lain yang juga memiliki nilai rata-rata effect size yang termasuk dalam kategori tinggi adalah model pembelajaran Inkuiri dengan nilai rata-rata effect size 1.39, model pembelajaran Kooperatif dengan nilai rata-rata effect size 1.11, model pembelajaran Discovery Learning dengan nilai 
rata-rata effect size 0.96 , serta model pembelajaran Problem Based Learning dengan nilai rata-rata effect size 0.92 .

\section{SIMPULAN DAN SARAN Kesimpulan}

Berdasarkan data yang telah dinyatakan dalam penelitian ini, maka dapat diambil kesimpulan bahwa model pembelajaran yang lebih efektif digunakan dalam meningkatkan pemahaman konsep fisika siswa yaitu model pembelajaran Langsung (Direct Instruction) dengan nilai rata-rata effect size 1.43 yang termasuk kategori tinggi.

\section{DAFTAR RUJUKAN}

Adam, A. A., Fatmaryanti, S. D., Sriyono. (2016). Efektivitas Model Pembelajaran Fisika Berbasis Guided Inquiry dalam Meningkatkan Pemahaman Konsep dan Kemandirian Belajar Siswa SMA. Radiasi, 9(2), 13-18.

Afandi, M., Chamalah, E., Wardani, O.P. (2013). Model dan Metode Pembelajaran di Sekolah. Semarang : UNISSULA Press.

Agustina, Misdalina, Lefudin. (2020). Pengaruh Model Pembelajaran Kooperatif Tipe Team Games Tournament Terhadap Pemahaman Konsep Peserta Didik Pada Pembelajaran Fisika. JPF Jurnal Pendidikan Fisika, 8(2), 186-195. DOI : http://dx.doi.org/10.24127/jpf.v8i2.2673

Amila, A. w., Abdurrahman, Suyatna, A., Wayan, I. D., \& Herlina, K. (2018). Practicallity and Affectiveness of Student' Worksheets Based on Ethno Science to Improve Conceptual Understanding in Rigid Body. International Journal of Advanced Enginering, Management and Science, 4(5), 400-407.

Anderson, L.W dan Karthwohl, D.R. (2001). A Taxonomy for Learning, Teaching, and Assesing ( A Revision of Bloom's Taxonomy of Educational Objectives). New York : Wesley Longman

Arend, R.I. (2012). Learning to Teach, Ninth Edition. America, New York : McGrawHill Companies, Inc.

Arianti, B. I., Sahidu, H., Harjono, A., Gunawan. (2016). Pengaruh Model Direct Instruction Berbantuan Simulasi Virtual Terhadap Penguasaan Konsep Siswa. Jurnal Pendidikan Fisika dan Teknologi, 2(4), 159-163.

Aristawati, N. K., Sadia, I. W., Sudiatmika, A. A. I. A. R. (2018). Pengaruh Model Problem Based Learning Terhadap
Pemahaman Konsep Belajar Fisika Siswa SMA. JPPF, 8(1).

Asrizal, Amran, Ananda, Festiyed, \& Sumarmin. (2018). The Development of Integrated Science Instructional Materials to Improve Students Digital Literacy in Scientific Approach. Jurnal Pendidikan IPA Indonesia, 7(4), 442-450.

Cohen, J. (1988). Statistical Power Analysis for The Behavior Science (2nd ed.). Hillsdale, NJ: Lawrence Erlbaum Associates.

Destalina, Ali, M. S., Palloan, P. (2019). Efektivitas Penerapan Discovery Learning Pada Pembelajaran Sains Berorientasi Inquiry Terhadap Pemahaman Konsep Fisika Peserta Didik Kelas XI IPA SMA Negeri 13 Makassar. Jurnal Sains dan Pendidikan Fisika (JSPF), 15(1), 1-7.

Departemen Pendidikan Nasional. 2006. Permendiknas nomor 22 tahun 2006. Jakarta

Diani, R., dkk. (2019). Scaffolding dalam Pembelajaran Fisika Berbasis Problem Based Instruction (PBL): Efeknya Terhadap Pemahaman Konsep dan Self Efficacy. Indonesian Journal of Science and Mathematics Education, 2(3), 310-319. DOI: 10.24042/ijsme.v2i3.4356.

Elisa, Dkk. (2017) Peningkatan Pemahaman Konsep Fisika dan Aktivitas Mahasiswa Melalui PhET Simulation. Jurnal Penelitian Tindakan Kelas dan Pengembangan Pembelajaran, 1(1). (diakses tanggal 15 januari 2019)

Husnia, Saehana, S., Ali, M. (2019). Pengaruh Model Pembelajaran Inkuiri Dengan Alat Sains Sederhana Terhadap Pemahaman Konsep Fluida Statis Pada Siswa Kelas Xi Sma Negeri 6 Palu. Jurnal Pendidikan Fisika Tadulako Online (JPFT), 7 (1), 12-16.

Izzah, N, Asrizal, Festiyed. (2021). Metaanalisis Effect size engaruh Bahan Ajar IPA dan Fisika Berbasis STEM Terhadap Hasil Belajar Siswa. JPF (Jurnal Pendidikan Fiska), 9(1), 114132.

Kemendikbud. (2014). Konsep dan Implementasi Kurikulum 2013. Jakarta: Kementrian Pendidikan dan Kebudayaan.

Mawarsih, Syamsu, Kamaluddin, H. (2016). Penerapan Model Pembelajaran Kooperatif Student Facilitator and Explaining untuk Meningkatkan Pemahaman Konsep Fisika pada Siswa Kelas X SMA Negeri 5 Palu. 
Jurnal Pendidikan Fisika Tadulako (JPFT), 4(3), 22-25.

Nurdyansyah, Fahyuni, E. F. (2016). Inovasi Model Pembelajaran Sesuai Kurikulum 2013. Sidoarjo : Nizamia Learning Center.

Nursyamsi, Muslimin, Hatibe, A. (2020). Pengaruh Model Pembelajaran Kooperatif Tipe SFAE Berbantuan Komik Edukatif Terhadap Pemahaman Konsep Fisika Siswa Kelas X SMA Negeri 1 Palu. Media Eksakta, 16(1), 11-15.

Pratiwi, I. (2019). Efek Program Pisa Terhadap Kurikulum Di Indonesia. Jurnal Pendidikan dan Kebudayaan, 4(1), 51.

Prihatiningtyas, S., Prastowo, T., \& Jatmiko, B. (2013). Implementasi Simulasi PhET dan Kit Sederhana untuk Mengajarkan Keterampilan Psikomotor Peserta didik pada Pokok Bahasan Alat Optik. Jurnal Pendidikan IPA Indonesia, 2(1).

Purnamasari, N., Habibi, Hidayat, S. (2016). Pengaruh Model Pembelajaran Langsung (Direct Instruction) dengan Pendekatan Kontekstual Terhadap Pemahaman Konsep Siswa. Jurnal IImiah Pendidikan Fisika "Lensa", 4(2), 51-54.

Riyadi, A. S., Mosik. (2014). Penerapan Metode Pembelajaran Kooperatif Tipe NHT Untuk Meningkatkan Pemahaman Konsep dan Komunikasi Ilmiah. Unnes Physics Education Journal, 3(2), 1-9.

Rosmiati, Hikmawati, Ahmad Harjono. (2020). Pengaruh Model Discovery Learning Terhadap Penguasaan Konsep Fisika Peserta Didik Kelas Xi Man 1 Lombok Barat. Jurnal Ilmiah Profesi Pendidikan, 5 (1): $29-34$

Safitri, B. R. A., dkk. (2018). Pengaruh Model Direct Instruction Kombinasi Multimedia Terhadap Pemahaman Konsep Fisika Siswa. Jurnal IImiah IKIP Mataram, 5(1), 63-66.

Sari, P. I., Gunawan, Harjono, A. (2016). Penggunaan Discovery Learning Berbantuan Laboratorium Virtual pada Penguasaan Konsep Fisika Siswa. Jurnal Pendidikan Fisika dan Teknologi, 2(4), 176-182.

Shoimin, A. (2014). 68 Model Pembelajaran Inovatif Dalam Kurikulum 2013. Yogyakarta: Ar-Ruzz Media.

Supriyanto, D. K., Jatmiko, B. (2017). Penerapan Model Pengajaran Langsung (Direct Instruction) pada Pembelajaran Fisika dengan Strategi Mind Mapping untuk Meningkatkan Pemahaman Konsep Pada Materi
Momentum dan Impuls Kelas X SMA Negeri 19 Surabaya. Jurnal Inovasi Pendidikan Fisika (JIPF), 6(3), 333340.

Taqwa, M. R. A., Rivaldo, L., Faizah, R. (2019). Implementasi Problem Based Learning dalam Meningkatkan Pemahaman Konsep Sisa pada Topik Elastisitas. Formatif: Jurnal IImiah Pendidikan MIPA, 9(2), 107-116.

Thalheimer, W., \& Cook, S. (2002). How to calculate effect sizes from published research articles: A simplified methodology. Diakses 07 Juni, 2021 dari learning.com/effect_sizes.htm.

Turrahmah, M., Susilawati, Makhrus, M., (2019). Pengaruh Model Discovery Learning Berbantuan Alat Praktikum Usaha dan Energi Terhadap Penguasaan Konsep Fisika Peserta Didik. Jurnal Pijar MIPA, 14(3), 118122. DOI: $10.29303 /$ jpm.v14i3.1329.

Ute, N., dkk. (2021). Pengaruh Metode Pembelajaran dengan Pendekatan Inkuiri Terbimbing Terhadap Pemahaman Konsep dan Motivasi Belajar Fisika. JPF (Jurnal Pendidikan Fisika) FKIP UM Metro, 9(1), 1-17. http://dx.doi.org/10.24127/jpf.v9i1.3524

Wati, A. L., Bukit, N. (2019). Efek Model Pembelajaran Inkuiri Berbantuan Pocket Book Terhadap Pemahaman Konsep Fisika Siswa. Jurnal Ikatan Alumni Fisika Universitas Negeri Medan, 5(4), 12-16.

Yulianti, E., Gunawan, I. (2019). Model Pembelajaran Problem Based Learning (PBL): Efeknya Terhadap Pemahaman Konsep dan Berpikir Kritis. Indonesian Journal of Science and Mathematics Education, 2(3), 399-408. DOI : 10.24042/IJSME.V2I3.4366. 